\title{
MEDETOMIDINE HYDROCHLORIDE EFFICIENCY AND SAFETY IN GUINEA PIG (Cavia porcellus), IN DOSES ESTIMATED THROUGH ALLOMETRIC EXTRAPOLATION
}

\author{
Evandro Poleze ${ }^{1}$ \\ David Brunson ${ }^{2}$ \\ Diogo Fernandes Giovanelli ${ }^{3}$ \\ Juliano Bortolo De Conti ${ }^{4}$ \\ Sheila Rezler Wosiacki ${ }^{5}$ \\ Salviano Tramontin Belettini ${ }^{6}$ \\ Evandra Maria Voltarelli Pachaly ${ }^{7}$ \\ José Ricardo Pachaly ${ }^{8}$
}

POLEZE, E.; BRUNSON, D.; GIOVANELLI, D. F.; De CONTI, J. B.; WOSIACKI, S. R.; BELETTINI, S. T.; VOLTARELLIPACHALY, E. M.; PACHALY, J. R. Efficacy and safety of medetomidine $\mathrm{HCl}$ in the guinea pig (Cavia porcellus) using an allometric scaling dosage technique. Arq. Ciênc. Vet. Zool. UNIPAR, Umuarama, v. 17, n. 2, p. 81-89, abr./jun. 2014.

\begin{abstract}
In this study, medetomidine hydrochloride, an alfa ${ }_{2}$ adrenergic receptor agonist, was administered to five adult guinea pigs (three males and two females) to verify the efficiency and safety of using doses calculated by using an allometric scale. A surgical procedure was performed to insert a polyethylene cannula that advanced 2.0 to $2.5 \mathrm{~cm}$ into the left carotid artery until the aorta. A minimum recovery period of two days was observed before any other manipulation or pharmacological test were performed. The cannulas were washed every two days with heparinized saline flow and remained patent for two to three weeks after insertion. After surgery, each animal was placed in an open box measuring $45 \times 25 \times 20 \mathrm{~cm}$, in a quiet room with soft lighting. The "MS" group received exactly the allometrically calculated dose, while the "2MS" group received twice the allometric dose and the " $1 / 2$ MS" group received half the allometric dose. Parameters were measured and analyzed at 0 , $5,10,20,40,60,90$ and 120 minutes after injection. Body mass was $709.6 \pm 169 \mathrm{~g}, 742 \pm 172.87 \mathrm{~g}$ and $710 \pm 160.2 \mathrm{~g}$ for groups 1,2 and 3, respectively. Body temperature was $101.68 \pm 0.19^{\circ} \mathrm{F}$; respiratory rate was $85.2 \pm 4.54$ strokes per minute; heart rate was $297.13 \pm 3.46$ beats per minute; $\mathrm{PaO}_{2}$ at $81.7 \pm 9.43 \mathrm{mmHg}$; $\mathrm{PaCO} 2$ at $34.49 \pm 1.59 \mathrm{mmHg}$; $\mathrm{pH}$ was measured at 7.41 \pm 0.07 ; hematocrit at $38.4 \pm 1.31 \%$; total protein was $4.33 \pm 0.29 \mathrm{~g} / \mathrm{dL}$, glucose was measured at $97.13 \pm 3.75 \mathrm{mg} / \mathrm{dL}$; systolic blood pressure was $85.53 \pm 2.50 \mathrm{mmHg}$; diastolic pressure at $7.40 \pm 3.74 \mathrm{mmHg}$; and mean blood pressure was $78.73 \pm 1.13 \mathrm{mmHg}$. Straightening postural reaction was lost at 7.20 $\pm 2.05,12.80 \pm 3.56$ and 8.67 \pm 3.06 minutes for groups " $2 \mathrm{MS}, \mathrm{MS}$ and $1 / 2 \mathrm{MS}$ ",

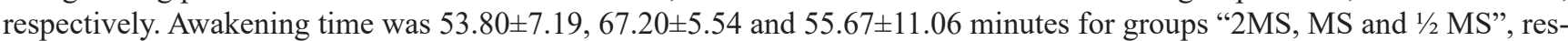
pectively. For the MS group, chemical restraint was considered "excellent" with "poor" analgesia, and for the $2 \mathrm{MS}$ group, it was considered "good", also with "poor" analgesia. This means these protocols should be used for painless procedures when immobilization is necessary. The $1 / 2 \mathrm{MS}$ protocol is not suitable for chemical restraint in guinea pigs. This paper presents new results obtained from research conducted in 2000 .
\end{abstract}

KEYWORDS: Allometry. Anesthesia. Laboratory animals. Chemical restraint. Rodents.

\section{EFICIÊNCIA E SEGURANÇA DO CLORIDRATO DE MEDETOMIDINA NO COBAIO (Cavia porcellus), EM DOSES CALCULADAS POR EXTRAPOLAÇÃO ALOMÉTRICA}

RESUMO: Neste estudo administrou-se cloridrato de medetomidina, um agonista de receptores adrenérgicos alfa ${ }_{2}$, a cinco cobaios adultos (três machos e duas fêmeas) para verificar a eficiência e segurança do uso de doses calculadas por meio de extrapolação alométrica. Um procedimento cirúrgico foi realizado para inserir uma cânula de polietileno que avançou 2,0 a 2,5 cm no interior da artéria carótida esquerda, até a aorta. Um período mínimo de recuperação de dois dias foi respeitado antes de qualquer outra manipulação ou teste farmacológico. As cânulas eram lavadas a cada dois dias com fluxo de solução salina heparinizada e permaneceram patentes por duas a três semanas após sua inserção. Após a cirurgia, cada animal foi colocado em uma caixa aberta medindo $45 \times 25 \times 20 \mathrm{~cm}$, em uma sala silenciosa com iluminação suave. O grupo "MS" recebeu exatamente a dose alometricamente calculada, enquanto o grupo " $2 \mathrm{MS}$ " recebeu o dobro da dose alométrica, e o grupo " $1 / 2$ MS" recebeu a metade da dose alométrica. Parâmetros foram mensurados e avaliados aos 0, 5, 10, 20, 40, 60, 90 e 120 minutos após a injeção. A massa corporal foi $709,6 \pm 169 \mathrm{~g}, 742 \pm 172,87 \mathrm{~g}$ e $710 \pm 160,2 \mathrm{~g}$ para os grupos 1 , 2 e 3 respectivamente, a temperatura corporal foi $101,68 \pm 0,19^{\circ} \mathrm{F}$, a frequência respiratória foi $85,2 \pm 4,54$ movimentos por minuto, a frequência cardía-

DOI: https://doi.org/10.25110/arqvet.v17i2.2014.4924

${ }^{1}$ DVM, MS, PhD. Director Poultry \& Swine Business Unit at Zoetis (Pfizer Animal Health), São Paulo, SP, Brazil. E-Mail: evandro.poleze@zoetis.com ${ }^{2}$ DVM, MS, DACVA. Veterinary Anesthesiologist at Zoetis (Pfizer Animal Health), Madison, WI, USA. E-Mail: david.brunson@pfizer.com

${ }^{3}$ DVM, MS. Clinician at Clínica Veterinária Mourãoense, Campo Mourão, PR, Brazil. E-Mail: dfgiovanelli@yahoo.com.br

${ }^{4} \mathrm{DVM}, \mathrm{MS}, \mathrm{PhD}$. Professor at Universidade Estadual de Maringá - UEM, Umuarama, PR, Brazil. E-Mail: julianodeconti@yahoo.com.br

${ }^{5}$ DVM, MS, PhD. Professor at Universidade Paranaense - UNIPAR Estadual de Maringá - UEM, Umuarama, PR, Brazil. E-Mail: wosiacki@yahoo.com.br ${ }^{6}$ DVM, MS. Professor at Universidade Paranaense - UNIPAR, Umuarama, PR, Brazil. E-mail: salviano@unipar.br

${ }^{7}$ DVM, MS. Technical Director at Brazilian Institute of Veterinary Specialties - ESPECIALVET, Maringá, PR, Brazil. E-mail: emvoltarelli@hotmail.com ${ }^{8}$ DVM, MS, PhD, PostDoc. Correspondence author. Professor at Master Degree Program in Animal Science, Universidade Paranaense - UNIPAR. Praça Mascarenhas de Moraes, s/n, Centro, Umuarama, Paraná, Brazil. E-mail: pachaly@uol.com.br, pachaly@especialvet.com.br 
ca foi $297,13 \pm 3,46$ batimentos per minute, a $\mathrm{PaO}_{2}$ foi $81,7 \pm 9,43 \mathrm{mmHg}$, a $\mathrm{PaCO}_{2}$ foi $34,49 \pm 1,59 \mathrm{mmHg}, \mathrm{o} \mathrm{pH}$ foi $7,41 \pm 0,07$, o hematócrito foi $38,4 \pm 1,31 \%$, a proteína total foi $4,33 \pm 0,29 \mathrm{~g} / \mathrm{dL}$, a glucose foi $97,13 \pm 3,75 \mathrm{mg} / \mathrm{dL}$, a pressão sistólica foi $85,53 \pm 2,50 \mathrm{mmHg}$, a pressão diastólica foi $71,40 \pm 3,74 \mathrm{mmHg}$, e a pressão sanguínea média foi $78,73 \pm 1,13 \mathrm{mmHg}$. A reação

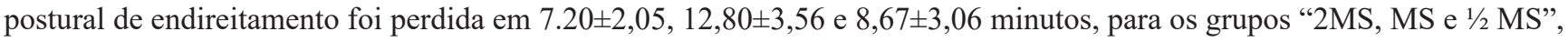

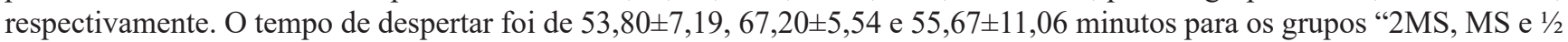
MS", respectivamente. Para o grupo MS, a contenção farmacológica foi considerada "excelente", com analgesia "ruim", e para o grupo 2MS foi considerada "boa", também com alangesia "ruim". Isso indica aqueles protocolos para procedimentos indolores em que é necessária imobilidade. O protocolo $1 \frac{1}{2} \mathrm{MS}$ protocol não é indicado para contenção farmacológica de cobaios. Este artigo resgata resultados inéditos obtidos em uma pesquisa finalizada em 2000.

PALAVRAS-CHAVE: Alometria. Anestesia. Animais de laboratório. Contenção farmacológica. Roedores.

\section{EFICIENCIA Y SEGURIDAD DEL CLORHIDRATO DE MEDETOMIDINA EN COBAYO (Cavia porcellus), EN DOSIS CALCULADAS POR EXTRAPOLACIÓN ALOMÉTRICA}

RESUMEN: En esta investigación se ha administrado clorhidrato de medetomidina, un agonista de receptores adrenérgicos alfa $_{2}$, a cinco cobayos adultos (tres machos y dos hembras) para verificar la eficacia y seguridad del uso de dosis calculadas por extrapolación alométrica. Se realizó un procedimiento quirúrgico para introducir una cánula de polietileno penetrando 2,0 a 2,5 cm en la arteria carótida izquierda, hasta la aorta. Se ha respetado un período mínimo de recuperación de dos días antes de cualquier otra manipulación o teste farmacológico. Las cánulas eran lavadas a cada dos días con flujo de solución salina heparinizada, y permanecieron patentes por dos a tres semanas después de la inserción. Después de la cirugía, cada animal fue acomodado en una caja abierta con medida de $45 \times 25 \times 20 \mathrm{~cm}$, en una sala silenciosa con iluminación suave. El grupo "MS" recibió exactamente la dosis alométricamente calculada, mientras el grupo "2MS" recibió el doble de la dosis alométrica, y el grupo “ $1 / 2$ MS” recibió la mitad de la dosis alométrica. Parámetros fueron mensurados y evaluados a los 0, 5, 10, 20, 40, 60, 90 y 120 minutos después de la inyección. El peso corporal fue 709,6 $\pm 169 \mathrm{~g}, 742 \pm 172,87 \mathrm{~g}$ y $710 \pm 160,2 \mathrm{~g}$ para los grupos 1,2 y 3 respectivamente, la temperatura corporal fue $101,68 \pm 0,19^{\circ} \mathrm{F}$, la frecuencia respiratoria fue $85,2 \pm 4,54$ movimientos por minuto, la frecuencia cardíaca fue $297,13 \pm 3,46$ batimientos por minuto, la $\mathrm{PaO}_{2}$ fue $81,7 \pm 9,43 \mathrm{mmHg}, 1 \mathrm{a} \mathrm{PaCO}$ fue $34,49 \pm 1,59 \mathrm{mmHg}$, el $\mathrm{pH}$ fue $7,41 \pm 0,07$, el hematocrito fue $38,4 \pm 1,31 \%$, la proteína total fue $4,33 \pm 0,29 \mathrm{~g} / \mathrm{dL}$, la glucosa fue $97,13 \pm 3,75 \mathrm{mg} / \mathrm{dL}$, la presión sistólica fue $85,53 \pm 2,50 \mathrm{mmHg}$, la presión diastólica fue $71,40 \pm 3,74 \mathrm{mmHg}, \mathrm{y}$ la presión sanguínea promedia fue $78,73 \pm 1,13 \mathrm{mmHg}$. La reacción postural de enderezamiento fue perdida en $7.20 \pm 2,05,12,80 \pm 3,56$

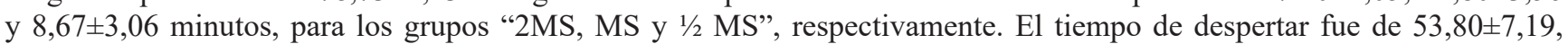

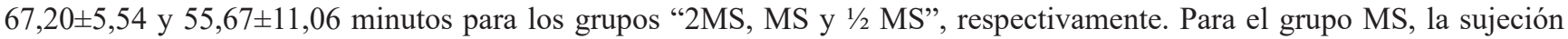
farmacológica fue considerada "excelente", con analgesia "mala", y para el grupo 2MS fue considerada "buena", también con analgesia "mala". Para los grupos 2MS y MS, la sujeción farmacológica fue considerada "excelente", con analgesia "mala". Esto indica aquellos protocolos para procedimientos indoloros en que se necesita inmovilidad. El protocolo $1 / 2 \mathrm{MS}$ no es indicado para sujeción farmacológica de cobayos. Este artículo rescata resultados inéditos obtenidos en una investigación finalizada en 2000.

PALABRAS CLAVE: Alometría. Anestesia. Animales de laboratorio. Sujeción farmacológica. Roedores.

\section{Introduction}

Wild animals present unique defensive behavior and reactions that differ from those observed in domestic animals. Thus, the main difference between domestic and wild animal medicine refers to the methods employed to approach and restraint the animals.

The restraint of wild animals, either free ranging or captive, may be done by physical or chemical methods, or by the combination of both. The selected restraint method needs to be safe for the animal and the involved staff, as well as permit the adequate handling and execution of medical or animal care procedure.

Drugs can be used for immobilization of wild animals without producing a general anesthetic effect. Frequently chemical methods of restraint are used by clinicians to perform medical procedures (as physical examination, collection of organic fluids and tissue samples, dental treatment and image diagnosis procedures) or husbandry procedures (as sexing, measuring, marking, and transportation).

In this paper we present the results of the medetomidine $\mathrm{HCl}$ as a sedative in Cavia porcelus, and test the efficacy and safety of interspecific allometric scaling as the basis for calculation of dosages. The dog was selected as a previously defined domestic species model. It is very important to note that Cavia porcellus is a typical hystricomorphic neotropical rodent, and so a model for other South-American wild rodents species.

The goal of this research is to identify a safe chemical restraint level for the patient and working staff. This method will contribute to improve conditions of study, handling and treatment of hystricomorphic rodents in zoo parks and other raising facilities, as well as in natural environment. Additionally we have collected data about biomedical features of Cavia porcellus. The data collected included rectal temperature, cardiac and respiratory frequency, blood pressure (systolic, diastolic and mean), blood gases $\left(\mathrm{pH}, \mathrm{PaO}_{2}\right.$, $\mathrm{PaCO}_{2}$ ), biochemical values (total protein, packed cells volume and glucose) of the animals during to chemical restraint.

\section{Literature Review}

A variety of drugs are used in veterinary medicine to tranquilize or sedate animals, and the alpha ${ }_{2}$-adrenoceptor agonists are among the most commonly used, as single agents or in combination with other classes of drugs. Nowadays me- 
detomidine is the most used alpha ${ }_{2}$-adrenoceptor agonist in small animal practice in North America and Europe, but it is being used in wild animal medicine too (PACHALY, 2000).

Researchers working with wild animals are challenged by a wide variety animal body shapes, sizes and basal metabolic rates. Such diversity creates a problem for the clinician, who must attempt estimate dosages of drugs from an animal to another (KIRKWOOD, 1983; PACHALY; BRITO, 2001; PACHALY, 2006). More than any other area of the veterinary medicine, the treatment with drugs in wild animals presents a high potential for wrongly calculated dosages, resulting in sub-dosage (inefficacy) or excessive dosages (toxicity) (PACHALY; BRITO 2001, PACHALY 2006).

Chemical restraint studies are difficult to conduct in wild species. This is due to the multiplicity of limiting factors, such as the huge variety of reptile species, birds and mammals kept in captivity by zoo parks and raising facilities. Additionally, the small number of captive animals of each species located in each institution, that in many cases are not suitable to biomedical research.

In wild animal practice deaths occurring during restraint procedures are frequently attributed to problems of calculating anesthetic or sedative dosages. This is because the calculations are generally empirical, based on dosages recommended for domestic animals and without considering the metabolic differences between the species involved. Over dosages may lead to death by generalized depression of the central nervous system, including cardio-respiratory centers. In the other hand, subdosages do not induce adequate anesthetic levels, and the animals may die of neurogenic shock, acidosis, and trauma during struggling or physical restraint (PACHALY, 2006).

It is necessary to search for rational dosage schedules based on scientific research but without the necessity of laboratory experimentation in each new species. A good alternative consists in a method of comparison of animals of different taxonomic groups, using their basal metabolic rate (BMR) as the main basis. Such method permits the scaling of dosages previously defined using pharmacokinetic studies in a given species, to an individual of another species. This method is known as "interspecific allometric scaling". The use of allometric scaling to propose rational therapeutic schedules is a recent concept. Gibbons et al. (1988), Sedgwick (1988), Sedgwick et al. (1990), Mader (1991), Sedgwick (1991), Pokras et al. (1992), Johnson et al. (1993), Sedgwick (1993), Harrison (1994), Marti; Sedgwick (1994), Quesenberry; Hillyer (1994), Sedgwick (1994), Timm et al. (1994), Jacobson (1995), Pachaly et al. (1995a,b,c,d), Pachaly; Brito (1995), Brito et al. (1995a,b,c,d), Sedgwick; Borkowski (1996), Pachaly; Brito (1996), Pachaly et al. (1996a,b), Dorrestein (1997), GAMBLE et al. (1997), Heard (1997) and Pachaly et al. (1997) used this method to calculate dosages of drugs to wild animals, while Costa et al. (1995) applied it in domestic animals.

Capybaras, pacas, agoutis and nutrias are frequently exhibited in zoo parks and are animals with long life expectancy, representing a considerable investment for institutions, which keep them in captivity. Further more these species are currently designated as threatened or endangered, demanding individual medical care (Pachaly et al., 2001).

As in other wild species, rodent chemical restraint is fundamental to handling and execution of medical procedures. At this time there is not a complete review on chemical restraint of wild rodents. However, articles describing the use of several anesthetic and sedatives agents have been published by authors interested in the use of rodent as a research animal model. These articles generally are oriented to a specific biomedical study and rarely are directed at the anesthetic technique used. The lack of previous knowledge in comparative anesthesia leads some investigators to accept and recommend anesthetic techniques that can be less than ideal. Often researchers accept the morbidity and mortality rates that are not acceptable in a clinic environment (STOSKOPF, 1979; PACHALY, 2006).

South-American rodent studies concerning to the use of sedative and anesthetic drugs have been published in capybaras (Hydrochaeris hydrochaeris) (STOSKOPF, 1979), chinchilla (Chinchilla laniger) (MORGAN et al., 1981), nutrias (Myocastor coypus) (BÓ et al.; 1994, PACHALY et al. 1999a), pacas (Agouti paca) (PACHALY, 1991; PACHALY 1992, PACHALY, 1996), porcupines (Sphiggurus villosus) (PACHALY et al., 1999c) and agoutis (Dasyprocta spp.) (BACHER et al., 1976; PACHALY, 1992; PACHALY; BRITO, 1995, PACHALY, 1998, PACHALY et al. 1999), all of them characteristic rodents of the neotropical fauna. The most part of these articles recommend the use of drugs based on observations of a small number of cases, and generally employing dosages calculated by empirical modes.

\section{Materials and Methods}

\section{Animals}

In this study, medetomidine $\mathrm{HCl}$, an adrenoceptor alpha ${ }_{2}$ agonist was administered to five 5 to12- month-old guinea pigs (three males and two females), weighing 550$1020 \mathrm{~g}$.

Animals were housed at Charmany Animal Research Facility of the School of Veterinary Medicine at the University of Wisconsin, in a room with temperature maintained at $70 \pm 2^{\circ} \mathrm{F}$ with a relative humidity of $35-55 \%$ and a 12 -hour light-dark cycle. The animals were handled every two days. This project was approved by the School of Veterinary Medicine, institutional animal care and use committee (2000-1DB), and carried out in the second semester of 2000.

\section{Study preparation}

A surgical procedure was performed in all the guinea pigs to place a carotid artery catheter, taking 30-40 minutes. The animals were induced with $5 \%$ isoflurane ${ }^{1}$ to reach general anesthesia and maintained in 2-3\% concentration administered by mask. The ventral surface of the neck was clipped and aseptically prepped. A 2-3 cm length incision was made on the ventral midline that approach of either the left or the right carotid artery. Using blunt dissection the sternhyoid muscle was separated and retracted to expose the trachea. The left carotid artery was isolated and ligated distally with 3-0 Silk. A cannula ${ }^{2}$ of polyethylene tubing $(0.86$

${ }^{1}$ Isoflo: Abbott, USA.

${ }^{2}$ PE90: Clay Adams, USA. 
$\mathrm{mm}$ ID x $1.27 \mathrm{~mm}$ OD) was inserted and advanced 2.0 to 2.5 $\mathrm{cm}$ into the left carotid artery towards the aorta and secured with a ligature. The distal end was tunneled subcutaneously and externalized between the scapulas. The catheter was filled with heparinized saline ( 75 units heparin/mL) and capped with a sterile injection cap. A recovery period of at least two days was allowed before any further manipulation or drug trial. Cannulas were flushed every two days with heparinized saline. Cannulas remained patent for two-three weeks after catheter placement. The incision was closed with interrupted suture using 3-0 monofilament nylon ${ }^{3}$.

\section{Physiological measurements}

After the post-surgical recovery period, each animal was placed in a $45 \times 25 \times 20 \mathrm{~cm}$ open-topped box in a moderately illuminated quiet room. Guinea pigs were allowed to acclimate before the study was begun. Baseline data was collected and time "zero" was designated as being the time of the injection of the study drug. Systolic, diastolic and mean arterial blood pressure were obtained with a pressure transducer and monitored continuously on a physiograph recorder. Data was displayed and stored by a "Ponemah Physiology Plataform" computer program, for the entire period. The heart rate was derived electronically from the arterial blood pressure waveforms. The respiratory rate was observed visually. An arterial blood sample $(0.15-0.20 \mathrm{~mL})$ was drawn through the catheter into a $1 \mathrm{~mL}$ syringe and kept on ice. Packed cell volume and total protein were determined using a micro-hematocrit tube and refractometer ${ }^{5}$, glucose was measured in a One Touch II Hospital Blood Glucose Meter ${ }^{6}, \mathrm{pH}$ and blood gases $\left(\mathrm{PaO}_{2}\right.$ and $\mathrm{PaCO}_{2}$ ) were measured in an ABL 500 radiometer ${ }^{7}$. Rectal temperature was obtained by using an electronic thermometer $^{8}$. The measurements were made at $0,5,10,20,40,60$, 90 and 120 minutes after the drug injection. Baseline values were obtained 5-10 minutes prior the drug injection.

The induced chemical restraint was evaluated by the loss of righting postural reaction ("righting reflex") where scores ( $1=$ absent response, $2=$ diminished response and $3=$ normal response) were given to the animals according to the beginning of the incapacity to react to human contact and manipulating. The activity level was related to myorrelaxation and immobility, independent of the analgesia level, where scores $(1=$ absent response, $2=$ diminished response and 3 = normal response) were given to the animals according to the excitement and the capability to react to contact and handling, evidencing the possibility of execution of medical procedures and the usual handling in the zoo park and raising routine. The jaw tone, chewing and corneopalpebral reflexes were evaluated on the mentioned times. Nociception was tested periodically, on the mentioned times, by the evaluation of a response to a firm pressure done in determined body parts, with a hemostat forceps. The pinched areas were a digit of the left thoracic limb and a digit of de left pelvic limb. The awakening time was evaluated according to the beginning of

${ }^{3}$ Dermalon: American Cyanamid, USA.

${ }^{4}$ Gould Instruments Systems, USA.

${ }^{5}$ Cambridge Instruments, USA.

${ }^{6} \mathrm{Johnson}$ and Johnson, USA.

${ }^{7}$ Radiometer Medical, USA.

${ }^{8}$ Heska Corporation, USA. conscious reactions stimulated by body manipulation, blow on the face, extern noises and return of the righting reflex. The recovery time was related to moment when the manipulation of the animal became impossible and it was observed the return of normal ambulating.

\section{Experimental protocol}

Each guinea pig received by intramuscular route three different dosages of medetomidine hydrochloride 9 . The order of treatment was assigned randomly, with a recovery period of at least two days between each drug trial. The dosages were calculated by interspecific allometric scaling, using previously defined pharmacokinetic studies for the domestic dog. The group " $2 \mathrm{MS}$ " received twice the allometric dosage. The group "MS" received the calculated allometric dosage and the group " $1 / 2 \mathrm{MS}$ " received $1 / 2$ allometric dosage.

\section{Statistical analysis}

To evaluate the influence of time and group on averages of analyzed parameters a two-way repeated measures analysis of variance test (ANOVA) was performed. The homogeneity of the observed variances was evaluated by the Bartlet's test $\left(\mathrm{X}^{2}\right)$. The significance evaluated using the $\mathrm{t}$-test - a "p" value $<0.05$ was considered significant. Graphs were made using the Excel program, version 9.0 (Microsoft Inc., 2000). Data related to righting reflex, heart rate, respiratory rate, rectal temperature, systolic, diastolic and mean pressure, packed cells volume, total protein and glucose, $\mathrm{pH}, \mathrm{PaO}_{2}$ and $\mathrm{Pa} \mathrm{CO}_{2}$ ), moment of awakening and return to normal ambulation were interpreted as mean average and standard deviation of the estimation $( \pm \mathrm{s})$, and with Fischer's test using the Statistic Analysis System ${ }^{10}$ (SAS) computer program.

\section{Results}

The animals' body weights were $709.6 \pm 169 \mathrm{~g}$, $742 \pm 172.87 \mathrm{~g}$ and $710 \pm 160.2 \mathrm{~g}$ to groups 1,2 and 3 respectively.

The temperature baseline value was $101.680 .19^{\circ} \mathrm{F}$, and there was a statistically significant difference $(\mathrm{p}=0.04)$ between group, time $(\mathrm{p}=0.0001)$ and group and time $(\mathrm{p}=0.0004)$.

The baseline value for respiratory rate was $85.2 \pm 4.54$ movements per minute. There was no statistically significant $(p=0.38)$ difference in respiratory rate between the groups, there was not a significant difference $(p=0.08)$ among the levels of time in the groups related to respiratory rate, and there was not a statistically significant interaction between group and time $(\mathrm{p}=0.62)$.

Concerning to resting guinea pigs' heart rate, the value was $297.13 \pm 3.46$ beats per minute, the differences in the mean values among the different levels of group were not statistically significant $(\mathrm{p}=0.18)$, the differences in the mean values among the different levels of time were statistically significant $(\mathrm{p}=0.0001)$, and there was a statistically interaction between group and time $(\mathrm{p}=0.02)$.

${ }^{9}$ Domitor ${ }^{\circledR}$, Orion-Farmos, Finland.

${ }^{10}$ Analydata Corp., Ann Arbor, USA. 
The baseline $\mathrm{PaO}_{2}$ value found for arterial blood was $81.7 \pm 9.43 \mathrm{mmHg}$, there was a statistically significant difference $(p=0.0001)$ between groups, among the levels of time in the groups $(\mathrm{p}=0.0001)$, and there was statistically significant interaction between group and time $(\mathrm{p}=0.0001)$.

For $\mathrm{PaCO}_{2}$, the baseline value for arterial blood found was $34.49 \pm 1.59 \mathrm{mmHg}$, there was no statistically significant difference $(p=0.19)$ between groups, among the levels of time in the groups $(p=0.18)$, and there was no statistically significant interaction between group and time $(\mathrm{p}=0.33)$.

The baseline value for $\mathrm{pH}$ was $7.41 \pm 0.07$, there was no statistically significant difference $(p=0.60)$ between groups, there was a difference between levels of time in the groups $(p=0.0008)$ what was expected, and there was also a statistically difference interaction between group and time $(\mathrm{p}=0.022)$.

The baseline value found for resting guinea pigs' packed cell volume was $38.4 \pm 1.31 \%$, the differences in the mean values among the different levels of group were not statistically significant $(p=0.67)$, the differences in mean values among the different levels of time were statistically significant $(\mathrm{p}=0.003)$, and there was not a statistically significant interaction between group and time $(p=0.62)$.

The baseline value for total protein in resting guinea pigs was $4.33 \pm 0.29 \mathrm{~g} / \mathrm{dL}$, the differences in the mean values among the different levels of group were not statistically significant $(\mathrm{p}=0.87)$, the differences in the mean values among the different levels of time were not statistically significant $(\mathrm{p}=0.056)$, and there was not a statistically interaction between group and time $(p=0.76)$.

For blood glucose, the baseline value for resting guinea pigs was $97.13 \pm 3.75 \mathrm{mg} / \mathrm{dL}$, the differences in the mean values among the different levels of group were statistically significant $(p=0.03)$, the differences in the mean values among the different levels of time were statistically significant ( $\mathrm{p}=0.0001)$, and there was not a statistically interaction between group and time $(p=0.16)$.

Concerning to systolic blood pressure, the baseline value for resting guinea pigs was $85.53 \pm 2.50 \mathrm{mmHg}$, the differences in the mean values among the different levels of group were not statistically significant $(p=0.12)$, the differences in the mean values among the different levels of time were statistically significant $(\mathrm{p}=0.0001)$, and there was a statistically interaction between group and time $(\mathrm{p}=0.0001)$.

The baseline value for diastolic blood pressure in resting guinea pigs was $71.40 \pm 3.74 \mathrm{mmHg}$, the differences in the mean values among the different levels of group were statistically significant $(p=0.045)$, the differences in the mean values among the different levels of time were statistically significant ( $\mathrm{p}=0.0001)$, and there was a statistically interaction between group and time $(\mathrm{p}=0.0006)$.

The baseline value for resting guinea pigs' mean blood pressure was $78.731 .13 \mathrm{mmHg}$, the differences in the mean values among the different levels of group were not statistically significant $(\mathrm{p}=0.055)$, the differences in the mean values among the different levels of time were statistically significant ( $\mathrm{p}=0.0001)$, and there was a statistically interaction between group and time $(\mathrm{p}=0.0001)$.

The means and standard deviations for loss of righting reflex were $7.20 \pm 2.05$ minutes, $12.80 \pm 3.56$ minutes and 8.67 \pm 3.06 minutes for the " $2 \mathrm{MS}, \mathrm{MS}$ and $1 / 2 \mathrm{MS}$ " groups respectively. In the $2 \mathrm{MS}$ and MS group, $100 \%$ (n: 5) of the animals lost their righting reflex. In the $1 / 2 \mathrm{MS}$ group, $40 \%$ (n: 5) of the animals did not lose the righting reflex.

The mean values and standard deviations for time of awakening post injection were 53.80 \pm 7.19 minutes, $67.20 \pm 5.54$ minutes and $55.67 \pm 11.06$ minutes to the " $2 \mathrm{MS}$, MS and $1 / 2$ MS" groups respectively. In the $1 / 2$ MS dosage, $40 \%$ (n: 5 ) of the animals did not lose the righting reflex and $60 \%$ (n: 5) were totally recovered within 90 minutes. In the MS dosage, $100 \%$ (n: 5) of the animals showed complete recovered within 120 minutes. In the $2 \mathrm{MS}$ dosage, $60 \%$ (n: 5) of the animals were totally recovered within 120 minutes and $40 \%$ (n: 5) were recovered within 90 minutes.

During the test, the activity level of the animals from the 2MS group was $50.37 \%$ of the time with score " 1 ", $7.86 \%$ with score " 2 " and $41.77 \%$ with score " 3 ". In the MS group, during the drug test the animals were $42.5 \%$ of the time with score " 1 ", $22.5 \%$ with score " 2 " and $35 \%$ with score " 3 ". In the $1 / 2$ MS group, during the drug test the animals were $28.58 \%$ of the time with score " 1 ", $28.58 \%$ with score "2" and $42.84 \%$ with score " 3 ".

Concerning to jaw tone, chewing reflex, nociception and corneopalpebral reflex, during the drug test the animals from the 2 MS group were $60.71 \%$ of the time with score " 2 ", and $39.29 \%$ with score " 3 ". In the MS group, during the drug test the animals were $57.5 \%$ of the time with score " 2 " and $42.5 \%$ with score " 3 ". In the $1 / 2$ MS group, during the drug test the animals were $59.99 \%$ of the time with score " 2 " and $40.01 \%$ with score " 3 ".

Finally, in none of the groups the animals lost either the nociception or the corneopalpebral reflex.

\section{Discussion and Conclusion}

The sex and the body weight did not interfere with the results but some of the differences found in this study may be attributed to factors such as animal strain, individual variability, degree of resting state of the animals, handling (pre and post procedure), duration of data collection period and period of data evaluation.

The difference in the mean values of temperature among the different levels of groups is not great enough to exclude the possibility that the difference is just due to random sampling. The respiratory depression is an expected sign when using alpha ${ }_{2}$ adrenoceptor agonist.

The animals were able to maintain the oxygen concentration during the drug trial. The variation in the arterial blood pressure, partial pressure of oxygen and carbon dioxide are presumably due stress related to instrumentation, manipulation or handling, depth of sedation, number and lengths of breaths, recumbency time and drug effects (FOWLER, 1986).

The changes in blood gas values, although statistically significant, are due to drug effect (hypotensive effects) but are not great enough to be functionally important in this study (may be if we have done some more animals). Presumably, environmental stress interfered in the values because each animal was allowed a minimum of 15 minutes in the test cage to avoid excitement prior administration of medetomidine $\mathrm{HCl}$ (FOWLER, 1986).

The animals were able to maintain different phy- 
siologic parameters in a safe range during the experimental protocol. Some of the obtained values can also be related to respiratory rate in order to be explained and assumed if the animal had either alkalosis or acidosis during the sedation (FOWLER, 1986).

The variation of total protein values can be related to the amount of flush during the drug trial (iatrogenic cause). The variation or increasing in glucose concentration after injection can be related to the alpha ${ }_{2}$ adrenoceptor agonist effects and depth of sedation (PACHALY, 2000).

The variation of systolic, diastolic and mean arterial pressure after injection can be related to the alpha ${ }_{2}$ adrenoceptor agonist effects (dose dependent) in the cardiovascular system and depth of sedation.

The variation observed in each measurement point after injection can be dose related and the MS group showed a longer awakening and recovery time.

The activity level can be directly related to the loss of righting reflexes, depth of sedation and drug dosage that determined the time and the quality of the recovery.

The allometric scaling technique has proven to be a safe and efficient process for the calculation of chemical immobilization protocols for rodents and other animals at all (PACHALY; BRITO 1995, PACHALY et al., 1995a,b,c,d; BRITO et al. 1995,a,b,c,d; PACHALY; BRITO 1996; PACHALY et al., 1996a,b; PACHALY et al., 1997; PACHALY; BRITO, 2001; PACHALY, 2006).

This study didn't show determining adverse factors that altered the responses of the cardiovascular, respiratory and central nervous systems.

The analgesia was considered "bad" because the animals presented intense painful reactions, characterized by evident discomfort situations, with some vocalization and vigorous body movements.

In the three different protocols (" $2 \mathrm{MS}, \mathrm{MS}, 1 / 2$ MS") the recovering quality was considered "excellent" because the animal remained calm, resting without reactions since the moment of being placed in the cage until recovering the normal ambulating. They didn't show any psychomotor excitement during recovering and didn't present severe awakening reactions with presence of trembling, agitation and convulsion.

The observed myorrelaxation that classified the quality of chemical restraint, independent of the analgesia level was considered "excellent" when the animal received the total allometric dosage (MS group) because they presented total immobility, evidencing the possibility of execution of medical and handling procedures. It was considered "good" when the animals received twice the allometric dosage (2MS group) presenting moderate handling reaction with discrete voluntary movement, being possible the execution of medical procedures without use of physical restraint method and "bad" when the animal received half allometric dosage $(1 / 2$ MS group) because 2 animals did not lose the righting reflex and struggled against the manipulation with voluntary movements making impossible the execution of medical procedures without the use of physical restraint.

\section{Acknowledgements}

This article refers to a study carried out from August $1^{\text {st }}$ to December $30^{\text {th }}$ of 2000 , when the first author (Poleze) attended an internship period at the Veterinary Medical Teaching Hospital of the University of Wisconsin (Madison, WI, USA), under coordination and advising of the second author (Brunson), with a special grant from the Research Institute of the Universidade Paranaense (IPEAC/UNIPAR, Umuarama, $\mathrm{PR}$, Brasil), and with supervision of the sixth author (PACHALY). We wish to thank both institutions.

\section{References}

BÓ, R. F. et al. Immobilization of coypus (Myocastor coypus) with ketamine hydrocloride and xylazine hydrochloride. Journal of Wildlife Diseases, Lawrence, v. 30, n. 4, p. 596-598, 1994.

BRITO, H. F. V. et al. Emprego da extrapolação alométrica interespecífica no cálculo da dose de cloridrato de xilazina e sulfato de atropina, para a contenção de um elefante africano (Loxodonta africana). In: SIMPÓSIO SOBRE CIÊNCIAS MÉDICAS E BIOLÓGICAS DO CURSO DE PÓS-GRADUAÇÃO EM CIÊNCIAS VETERINÁRIAS DA UNIVERSIDADE FEDERAL DO PARANÁ, 2., 1995, Curitiba. Anais... Curitiba: CPGCV-UFPR, 1995a, p. 12.

BRITO, H. F. V. et al. Emprego do cloridrato de detomidina, em associação a cloridrato de ketamina e sulfato de atropina, para a contenção de um tigre (Panthera tigris), com base em extrapolação alométrica interespecífica. In: SIMPÓSIO SOBRE CIÊNCIAS MÉDICAS E BIOLÓGICAS DO CURSO DE PÓS-GRADUAÇÃO EM CIÊNCIAS VETERINÁRIAS DA UNIVERSIDADE FEDERAL DO PARANÁ, 2., 1995b, Curitiba. Anais... Curitiba: CPGCV-UFPR, 1995b, p. 13.

BRITO, H. F. V. et al. Emprego do cloridrato de xilazina, em associação a sulfato de atropina, na contenção de um tigre (Panthera tigris), com base em extrapolação alométrica interespecífica. In: SIMPÓSIO SOBRE CIÊNCIAS MÉDICAS E BIOLÓGICAS DO CURSO DE PÓS-GRADUAÇÃO EM CIÊNCIAS VETERINÁRIAS DA UNIVERSIDADE FEDERAL DO PARANÁ, 2., 1995, Curitiba. Anais... Curitiba: CPGCV-UFPR, 1995c, p. 14.

BRITO, H. F. V. et al. Emprego de cloridrato de detomidina em associação a cloridrato de tiletamina, zolazepam e sulfato de atropina, na contenção de um puma (Felis concolor), com base em extrapolação alométrica. In: JORNADA DE MEDICINA DE ANIMAIS SELVAGENS E DE PEQUENOS RUMINANTES DO CONE SUL, 1 ., 1995, Curitiba. Anais... Curitiba: Sociedade Paranaense de Medicina Veterinária, 1995d. p. 2.

COSTA, R. C. et al. 1995. Uso de um neuroléptico de ação prolongada (decanoato de haloperidol) no tratamento de dermatite psicogênica em gato doméstico. In: SIMPÓSIO SOBRE CIÊNCIAS MÉDICAS E BIOLÓGICAS DO CURSO DE PÓS-GRADUAÇÃO EM CIÊNCIAS VETERINÁRIAS DA UNIVERSIDADE FEDERAL DO PARANÁ, 2., 1995, Curitiba. Anais... Curitiba: CPGCVUFPR, 1995, p. 22. 
DORRESTEIN, G. M. Metabolism, pharmacology and therapy. In: ALTMAN, R.B. et al. Avian Medicine and Surgery. Philadelphia: W. B. Saunders, 1997. p. 661-670.

FOWLER, M.E. Stress. In Zoo \& wild animal medicine. 2. ed. Philadelphia: W.B. Saunders, 1986. p. 3435.

GAMBLE, K. C. et al. Pharmacokinetics of a single intraveous enrofloxacin dose in scimitar-horned orix (Oryx dammah). Journal of Zoo and Wildlife Medicine. Michigan, v. 28, n. 1, p. 36-42, 1997.

GIBBONS, G. et al. Allometric scaling in veterinary medicine. Australian Veterinary Practitioner, St. Leonards, v. 18, n. 4, p. 160-164, 1988.

HARRISON, G. J. Determination of metabolic scaling. In: Ritchie B. W. et al. Avian Medicine. Lake Worth: Wingers, 1994. p. 1351-1361.

HEARD, D. J. Anesthesia and analgesia. In: ALTMAN R.B et al. Avian Medicine and Surgery. Philadelphia: W. B. Saunders, 1997. p. 807-827.

JACOBSON, E. R. Use of antimicrobial therapy in reptiles. In: NORTH AMERICAN VETERINARY CONFERENCE, 1995, Orlando. Proceedings... Orlando: American Veterinary Medical Association, 1995, p. 28-37.

JOHNSON, J. H. et al. Gentamicin toxicosis in a North American cougar. Journal of the American Veterinary Medical Association, Washington, v. 203, n. 6, p. 854-856, 1993.

KIRKWOOD, J. K. Influence of body size in animals on health and disease. Veterinary Record, London, v. 113, n. 13, p. 287-290, 1983.

MADER, D. R. Metabolic scaling of antibiotic dosages. In: FRYE, F. L. Reptile Care: An atlas of diseases and treatments. Neptune City: The TFH Publications Inc., 1991. p. 632-633.

MARTIN, J. C.; SEDGWICK, C. J. A review on allometric scaling with considerations for its application to reptile therapeutics. In: AMERICAN ASSOCIATION OF ZOO VETERINARIANS ANNUAL CONFERENCE, 1994, Pittsburgh. Proceedings... Pittsburgh: AAZV, 1994. p. 6265.

MORGAN, R. J. et al. Ketamine-acepromazine as an anaesthetic agent for chinchillas (Chinchilla laniger). Laboratory Animals, v. 15, p. 281-283, 1981.

PACHALY, J. R. Chemical restraint and anesthesia in the paca (Agouti paca, Rodentia) In: WORLD VETERINARY CONGRESS, 26., 1991, Rio de Janeiro. Proceedings... Rio de Janeiro: World Veterinary Association, 1991, p. 196.

Estudo da utilização da associação cloridrato de cetamina, maleato de acetilpromazina e sulfato de atropina na contenção de Agouti paca (Linnaeus, 1766) [Rodentia: Mammalia]. Curitiba, 1992. 70 f. Dissertação. (Mestrado em Ciências Veterinárias) - Setor de Ciências Agrárias, Universidade Federal do Paraná. Curitiba, 1992.

. Estudo da utilização da associação cloridrato de cetamina, maleato de acetilpromazina e sulfato de atropina na contenção de Agouti paca (Linnaeus, 1766) [Rodentia: Mammalia]. Archives of Veterinary Science, Curitiba, v. 1, n., p. 15, 1996.

\section{Contenção da cutia, Dasyprocta azarae}

(Rodentia: Mammalia), pela associação de cloridrato de cetamina, cloridrato de xilazina e sulfato de atropina: Definição de protocolos posológicos individuais com base em extrapolação alométrica interespecífica. Curitiba, 1998. 90 f. Tese. (Doutorado em Zoologia) - Setor de Ciências Biológicas, Universidade Federal do Paraná. Curitiba, 1998.

. Principais drogas empregadas na contenção farmacológica de animais selvagens. Arquivos de Ciências Veterinárias e Zoologia da UNIPAR. Umuarama, v. 3, n. 1, p. 87-94, 2000

. Order Rodentia (Rodents). In: FOWLER, M. E.; CUBAS, Z. S. Biology, Medicine and Surgery of South American Wild Animals. Ames: Iowa University Press, 2001. p. 225-237.

Terapêutica por extrapolação alométrica. In: CUBAS, Z. S. et al. Tratado de animais selvagens Medicina veterinária. São Paulo: Roca, 2006. p. 12151223.

PACHALY, J. R. et al. Emprego de cloridrato de xilazina, em associação a cloridrato de tiletamina, zolazepam e sulfato de atropina na contenção de um leão (Panthera leo), com base em extrapolação alométrica. In: JORNADA DE MEDICINA DE ANIMAIS SELVAGENS E DE PEQUENOS RUMINANTES DO CONE SUL, 1., 1995, Curitiba. Anais... Curitiba: Sociedade Paranaense de Medicina Veterinária, 1995a. p. 1.

PACHALY, J. R. et al. Emprego de cloridrato de detomidina em associação a cloridrato de tiletamina, zolazepam e sulfato de atropina, na contenção de duas onças (Panthera onca), com base em extrapolação alométrica. In: JORNADA DE MEDICINA DE ANIMAIS SELVAGENS E DE PEQUENOS RUMINANTES DO CONE SUL, 1., 1995, Curitiba. Anais... Curitiba: Sociedade Paranaense de Medicina Veterinária, 1995b. p. 2.

PACHALY, J. R. et al. Emprego de cloridrato de detomidina, em associação a cloridrato de tiletamina, zolazepam e sulfato de atropina, na anestesia cirúrgica de um cervo sambar (Cervus unicolor), com base em extrapolação alométrica interespecífica. In: SIMPÓSIO SOBRE CIÊNCIAS MÉDICAS E BIOLÓGICAS DO CURSO DE PÓS-GRADUAÇÃO EM CIÊNCIAS 
VETERINÁRIAS DA UNIVERSIDADE FEDERAL DO PARANÁ, 2., 1995, Curitiba. Anais... Curitiba: CPGCVUFPR, 1995c, p. 50.

PACHALY, J. R. et al. 1995d. Emprego de cloridrato de detomidina em associação a cloridrato de tiletamina, zolazepam e sulfato de atropina, na contenção de duas leoas (Panthera leo), com base em extrapolação alométrica. In: SIMPÓSIO SOBRE CIÊNCIAS MÉDICAS E BIOLÓGICAS DO CURSO DE PÓS-GRADUAÇÃO EM CIÊNCIAS VETERINÁRIAS DA UNIVERSIDADE FEDERAL DO PARANÁ, 2., 1995, Curitiba. Anais... Curitiba: CPGCV-UFPR, 1995d, p. 51.

PACHALY, J. R.; BRITO, H. F. V. 1995. Emprego de cloridrato de detomidina, em associação a cloridrato de ketamina e sulfato de atropina, na contenção de cutias (Dasyprocta azarae), com base em extrapolação alométrica. In: JORNADA DE MEDICINA DE ANIMAIS SELVAGENS E DE PEQUENOS RUMINANTES DO CONE SUL, 1., 1995, Curitiba. Anais... Curitiba: Sociedade Paranaense de Medicina Veterinária, 1995. p. 1.

PACHALY, J. R.; BRITO, H. F. V. Emprego da extrapolação alométrica na definição de protocolos anestesiológicos individuais para animais selvagens. In: CONGRESSO PANAMERICANO DE CIÊNCIAS VETERINÁRIAS, 15., Campo Grande. Anais... Campo Grande: Sociedade Brasileira de Medicina Veterinária, 1996, p. 75.

PACHALY, J. R. et al. Uso de medetomidina na contenção farmacológica de um ratão-do-banhado (Myocastor coypus), e antagonismo pelo atipamezole. In: CONGRESSO DE CLÍNICOS VETERINÁRIOS DE PEQUENOS ANIMAIS DO MERCOSUL, 1., 1999, Foz do Iguaçu. Anais... Foz do Iguaçu: ANCLIVEPA-PR, 1999a. p. 40.

PACHALY, J. R. et al. Uso de medetomidina na contenção farmacológica de cutias (Dasyprocta azarae): Relato de três casos. In: CONGRESSO DE CLÍNICOS VETERINÁRIOS DE PEQUENOS ANIMAIS DO MERCOSUL, 1., 1999, Foz do Iguaçu. Anais... Foz do Iguaçu: ANCLIVEPA-PR, 1999b. p. 39

PACHALY, J. R. et al. Contenção farmacológica de ouriçoscacheiros (Sphiggurus villosus) pela associação de xilazina, tiletamina, zolazepam e atropina: doses calculadas por extrapolação alométrica interespecífica. In: CONGRESSO DE CLÍNICOS VETERINÁRIOS DE PEQUENOS ANIMAIS DO MERCOSUL, 1., 1999, Foz do Iguaçu. Anais... Foz do Iguaçu: ANCLIVEPA-PR, 1999c. p. 38.

PACHALY, J.R. et al. Anestesia em leão (Panthera leo) pela associação de cloridrato de xilazina, sulfato de atropina, cloridrato de tiletamina e zolazepam em três ocasiões diferentes: protocolo posológico calculado por meio de extrapolação alométrica interespecífica. In: CONGRESSO BRASILEIRO DE CLÍNICOS VETERINÁRIOS DE PEQUENOS ANIMAIS, 19, 1997, Curitiba. Anais.. Curitiba: ANCLIVEPA-PR, 1997, p. 21.
PACHALY, J. R. et al. Emprego de cloridrato de tiletamina e zolazepam, em associação a cloridrato de romifidina e sulfato de atropina, na anestesia de um cavalo doméstico (Equus caballus), com base em cálculos de extrapolação alométrica interespecífica. Archives of Veterinary Science, Curitiba, v. 1, n. 1, p. 38. 1996a.

PACHALY, J. R. et al. Emprego de decanoato de haloperidol na modulação comportamental de um grupo de cervos nobres (Cervus elaphus). In: CONGRESSO PANAMERICANO DE CIÊNCIAS VETERINÁRIAS, 15., Campo Grande. Anais... Campo Grande: Sociedade Brasileira de Medicina Veterinária, 1996b, p. 75.

PACHALY, J. R. et al. Emprego de decanoato de haloperidol na modulação comportamental de um casal de onças (Panthera onca). In: CONGRESSO PANAMERICANO DE CIÊNCIAS VETERINÁRIAS, 15., Campo Grande. Anais... Campo Grande: Sociedade Brasileira de Medicina Veterinária, 1996c, p. 75.

PACHALY, J. R. et al. 1995. Emprego de cloridrato de detomidina em associação a cloridrato de tiletamina, zolazepam e sulfato de atropina, na anestesia de um gnu (Connochaetes gnou). In: SIMPÓSIO SOBRE CIÊNCIAS MÉDICAS E BIOLÓGICAS DO CURSO DE PÓSGRADUAÇÃO EM CIÊNCIAS VETERINÁRIAS DA UNIVERSIDADE FEDERAL DO PARANÁ, 2., 1995, Curitiba. Anais... Curitiba: CPGCV-UFPR, 1995, p. 56.

PACHALY, J. R.; BRITO, H. F. V. Interespecific allometric scaling. In: FOWLER M. E.; CUBAS Z. S. Biology, medicine and surgery of South American wild animals. Ames: Iowa University Press, Ames, 2001. p. 475-481.

POKRAS, M. A. et al. Therapeutics. In: BEYNON, P. H. Manual of Reptiles. Gloucestshire: British Small Animal Veterinary Association, 1992. p.194-209.

QUESENBERRY, K. E.; HILLYER, E. V. Supportive care and emergency therapy. In: RITCHIE B. W. Avian Medicine: Principles and application. Lake Worth: Wingers, 1994. p. 382-416.

SEDGWICK, C. J. Anesthetic and chemical restraint techniques for zoo animals and wildlife. In: ANNUAL MEETING OF THE AMERICAN ANIMAL HOSPITALS ASSSOCIATION, 55., 1988, St. Louis. Proceedings... St. Louis: AAHA, 1988. p. 162-166

Allometrically scaling the data base for vital sign assessment used in general anesthesia of zoological species. In: AMERICAN ASSOCIATION OF ZOO VETERINARIANS ANNUAL CONFERENCE, 1991, Calgary. Proceedings... Calgary: AAZV, 1991. p. 360-369.

Allometric scaling and emergency care: The importance of body size. In: FOWLER M.E. Zoo and Wild Animal Medicine, 3. ed. Philadelphia: W. B. Saunders, 1993. p. 34-37. 
Grisefulvin toxicity in zoo cats. Zoo Veterinary

News, Philadelphia, v. 10, n. 3, p. 11-12, 1994.

SEDGWICK, C. J.; BORKOWSKI, R. Allometric scaling: extrapolating treatment regimens for reptiles. In: MADER D. R. Reptile Medicine and Surgery. Philadelphia: W. B. Saunders, 1996. p. 235-240.

SEDGWICK, C. J. et al. Metabolic scaling: Using estimated energy costs to extrapolate drug doses between different species and different individuals of diverse body sizes. In: AMERICAN ASSOCIATION OF ZOO VETERINARIANS ANNUAL CONFERENCE, 1990, South Padre Island. Proceedings... South Padre Island: AAZV, 1990, p. 249254.

STOSKOPF, M. K. 1979. Anesthesia of zoo rodents. In: AMERICAN ASSOCIATION OF ZOO VETERINARIANS ANNUAL CONFERENCE, 1979, Philadelphia.

Proceedings... Philadelphia: AAZV, 1979. p. 68-69.

TIMM, K. L. et al. Surface area to volume relationships of snakes support the use of allometric scaling for calculating dosages of pharmaceuticals. Laboratory Animal Science. v. 44, n. 1, p. 60-62, 1994.

Recebido em: 28/04/2014

Aceito em: 03/05/2014 